\title{
Status and distribution of the globally threatened Bristled Grassbird Chaetornis striata (Jerdon, 1841) (Fam. Sylviidae) in Nepal
}

\author{
Hem Sagar Baral ${ }^{1}$, Jan Wattel ${ }^{2}$, Philip A. Brewin ${ }^{3}$ and Steve J. Ormerod ${ }^{3}$ \\ Corresponding Author: Hem Sagar Baral \\ Email: hem.baral@gmail.com
}

\begin{abstract}
:
Lowland grasslands in Nepal were thoroughly surveyed in 1996-1999 to assess the status and distribution of the globally threatened Bristled Grassbird Chaetornis striata. Birds were located on foot, from elephants and from jeeps by sight and sound backed up by mistnets and tape playback. The status information was updated again by visiting these areas in 2010-2012. Bristled Grassbirds were recorded in Sukla Phanta and Koshi Tappu Wildlife Reserves, and Chitwan National Park where most of the Nepal population is confined. From the research, it was found that they were most associated with newly formed Saccharum and Imperata dominated grasslands during summer. The low numbers present during winter suggested that this species was primarily a summer migrant to Nepal. A total population for Nepal is presented based on a reliable density estimate. Loss and degradation of grassland habitat and invasion of Mikania micrantha were identified as the major threats. Further research on migratory status, better control of cattle grazing inside reserves, expansion of Protected Areas to include more grassland, and listing of Bristled Grassbird as protected under the wildlife law of Nepal for its conservation are highly recommended.
\end{abstract}

Key Words : Bristled Grassbird, Habitat association, Population, Lowland grasslands, Nepal

\section{Introduction}

The Bristled Grassbird Chaetornis striata (Jerdon, 1843) is endemic to the Indian subcontinent and is found in Pakistan, India, Nepal and Bangladesh (Ali and Ripley, 1987; Roberts, 1992; Grimmett et al., 1998 and Bird Life International, 2001). It is one of the least known of all the globally threatened birds in the Indian subcontinent (Inskipp, 1996). Its small and rapidly declining population is threatened to extinction due to loss and degradation of grassland habitat, primarily through drainage and conversion to agriculture land (BirdLife International, 2001).Very limited information exists about the species' status, distribution

${ }^{1}$ Himalayan Nature, PO Box 10918, Lazimpat, Kathmandu, Nepal

${ }^{2}$ Pr Irenelaan 9, 1911 HT Uitgeest, the Netherlands

${ }^{3}$ Cardiff School of Biosciences, Cardiff University, Museum Avenue, Cardiff CF10 3AX, UK 
and ecology (Inskipp, 1996). Since the literature review by Inskipp (1996), there have been only two short articles on this species by Baral (1997) and Sharma (2007). There are particular gaps in knowledge with respect to its seasonal movement, and the assumed wintering area in central India, whichis based largely on historical records and anecdotalnotes (Rasmussen and Anderton, 2005; del Hoyo et al., 2006). Available information on the distribution andbreeding ecology is scarce and a summary can be found in the book 'Threatened Birds of Asia' (BirdLife International, 2001).

Following the publication of the 'Birds to Watch 2' (Collar et al., 1994), various papers on the status of Bristled Grassbird (Inskipp, 1996; Grewal, 1996 and Baral, 1997) and publication by BirdLife International $(2000,2001)$ on the globally threatened birds, significant interest and awareness have been noted on the status and conservation of this bird. As a result, more information has been available on its status and distribution. Although there are reports of Bristled Grassbird occurrence from different areas, no special efforts have been made especially to look for this species in Nepal until recently.

This paper provides data on the status of Bristled Grassbird in Nepal with a reference to its wider status in the rest of the Indian subcontinent. We present our results from surveys during breeding and winter, and also discuss the migratory status and population of the species in the country.

\section{Study Area}

Grasslands were surveyed in Koshi Tappu Wildlife Reserve (hereafter 'Koshi Tappu'), $26^{\circ}$ $35^{\prime}-26^{\circ} 40^{\prime} \mathrm{N} / 86^{\circ} 56^{\prime}-87^{\circ} 04^{\prime} \mathrm{E}$, Chitwan National Park (hereafter 'Chitwan'), $27^{\circ} 15^{\prime}$ $27^{\circ} 35^{\prime} \mathrm{N} / 83^{\circ} 45^{\prime}-84^{\circ} 58^{\prime} \mathrm{E}$ and Sukla Phanta Wildlife Reserve (hereafter 'Sukla Phanta'), $28^{\circ} 49^{\prime}-28^{\circ} 57^{\prime} \mathrm{N} / 80^{\circ} 07^{\prime}-80^{\circ} 15^{\prime} \mathrm{E}$. The surveys were conducted from January 1996 to May 2012 in drier months (October till May).

Koshi Tappu was gazzetted as Protected Areas in 1976 and occupies 17500 ha of the Sapta Koshi River floodplain at the most northeasterly extension of the Gangetic Plain. It ranges in altitude from 75 - $81 \mathrm{~m}$ (IUCN, 1993). The reserve is located between two flood control embankments and is subject to annual flooding. Approximately $70 \%$ of the reserve's land area is covered in grasslands (Heinen, 1993); although during high flood years a large amount of grassland is destroyed and replaced by new alluvial deposits.

Chitwan is an inner doon valley in the central terai of Nepal between the Siwalik hills in the south and the Mahabharat hills to the north. All other Protected Areas in lowland Nepal lie south of the outermost ranges of Himalaya known as Siwalik hills. The park ranges in altitude from $150 \mathrm{~m}$ to $815 \mathrm{~m}$ (IUCN, 1993). The total area of Chitwan is 93200 ha and is bordered by Parsa Wildlife Reserve (49900 ha) in the east. It is located in the drainage basin of three major rivers: Narayani, Rapti and Reu. Chitwan has numerous small patches of grasslands, lying alongside the rivers. Approximately $70 \%$ of the park is covered by sal forest (Laurie 1979), the remainder being grassland and riverine forests (Gurung, 1983). 
Sukla Phanta was gazzetted as a Protected Areas in 1976 and the reserve lies in the extreme southwest of the terai and covers 30500 ha area, ranging in altitude from $150 \mathrm{~m}$ to $600 \mathrm{~m}$ (Baral and Inskipp, 2005). One third of the reserve is covered by mixed deciduous forest, grassland and marsh in the southwest where soils are of recent alluvium (Department of National Parks and Wildlife Conservation, 2000). The remainder of the Reserve is moist deciduous forest and savannah, supported by better-drained soils on higher terrain in the northeast. The reserve possesses the largest grassland phantas in Nepal (Baral, 2001).

Similarly, two grassland sites of Bardia National Park $28^{\circ} 28^{\prime} \mathrm{N} / 81^{\circ} 28^{\prime} \mathrm{E}$ and different grassland patches at Lumbini $\left(27^{\circ} 29^{\prime} \mathrm{N} 53^{\circ} 17^{\prime} \mathrm{E}\right)$, Rupandehi District and at Koshi Tappu were also searched in March 1998. Two visits each year were made in 2010 and 2011 to the study sites mentioned above to gauge the changes in bird populations.

\section{Methods}

The grassland types were identified based on grass species composition and their relative dominance. Habitat variables like grass species' composition, distance to forest, sward height etc. were analyzed to find out their relationship with grass assemblage, classification proposed by Peet et al. (1999). Furthermore, Bristled Grassbird and its association with different grass assemblage were identified.

All bird surveys were carried out between $07 \mathrm{~h} 00$ and $11 \mathrm{~h} 00$, when grassland birds were most active. In addition to this a tape playback method to detect bird presence was carried out in selected potential grasslands at Chitwan, Koshi and Sukla Phanta.

Minolta Waterproof 10 X 50 and Optolyth 10 X 50 binoculars were used for identifying the birds. Sony TCM 300 Sound Recorder was used to record bird calls and for play back of the bird calls.

\section{Line transect study}

Grassland bird communities and environmental variables were recorded along 59 transects in the three Protected Areas (Koshi Tappu, Chitwan and Sukla Phanta) between January 1996 and May 1998. A transect varied in length from $100 \mathrm{~m}$ to $1300 \mathrm{~m}$. Each $100 \mathrm{~m}$ of a transect was termed a section. For statistical analysis a selection was made of records assembled in transect sections visited at least 5 times in one of the four sampling seasons: Dec 96 - Feb 97, Mar 97- May 97, Dec 97- Feb 98, Mar 98 - Jun 98 (see Baral, 2001).

\section{Call playback and mist-netting during winter search}

This method included direct observation of the birds, taped call playback as well as mist netting during the winter months in selected grasslands where the species had been seen during the previous summer months. Calls of Bristled Grassbird, Striated Grassbird Megalurus palustris and Rufous-rumped Grassbird Graminicola bengalensis were familiarized to eliminate confusion in identification. The surveys were conducted on foot, from jeeps and 
from boats. Domestic elephants were used where the grasses were tall and impregnable by other means of travel especially during summer months.

Grasslands at Chitwan including former Padampur Village, near Sauraha were searched extensively in October 1997 for 15 days. Two domesticated elephants were used almost four hours each morning for an intensive search to cover grasslands of central and eastern part of Chitwan. Bristled Grassbirds were observed disturbed by elephants during simultaneous drive of elephants through the tall grasslands and lured by the taped call playback.

The grasslands were surveyed by using tape playback in November and December 1997 as well as in March 1998 in Sukla Phanta. Sites were chosen to include areas where Bristled Grassbird had been seen commonly during the summer of 1996 and 1997. To find out if the birds used different habitats during winter, taped call was also played close to wet grasslands dominated by Phragmites karka and Saccharum arundinaceum. Similarly, two grassland sites of Bardia National Park $28^{\circ} 28^{\prime} \mathrm{N} / 81^{\circ} 28^{\prime} \mathrm{E}$ and some grasslands at Lumbini $\left(27^{\circ} 29^{\prime} \mathrm{N}\right.$ $\left.53^{\circ} 17^{\prime} \mathrm{E}\right)$, Rupandehi District and at Koshi Tappu in March 1998 were also searched. Two visits each year were made from 2010 to 2012 in the study sites mentioned above to gauge the changes in bird populations.

\section{Data analysis}

Line transects' count data were used to assess specific habitat association of the species. Observation outside the transect were analyzed independently to further iterate their habitat associations. Similarly, birds that were seen during summer at different sites were added carefully to count total number of the birds observed. Based on the habitat available for the species mainly in the 4 Protected Areas of the lowland and some grasslands outside the Protected Areas, their total population for Nepal was estimated. Different estimates on population were proposed with varying range of bird densities. A more realistic density was chosen to come up with its total population in Nepal.

\section{Results}

\section{Habitat Association}

There were 27 observations of Bristled Grassbird during line transect counts most frequently in open grassland, followed by intermediate grasslands (Figure 1). Among the grasslands, the species showed preference for open grasslands. Of the open grasslands, it preferred Imperata grasslands with Saccharum spontaneum and Narenga porphyrocoma as codominant species (Figure 2). It was absent in grasslands from forested areas. Because of larger number of samples of Imperata in Sukla Phanta, the species appeared to be more abundant there compared to Chitwan. However, the bird was found equally abundant at Chitwan and Koshi Tappu. This was mainly because of unequal ratio of different grassland assemblages sampled in different Protected Areas. 


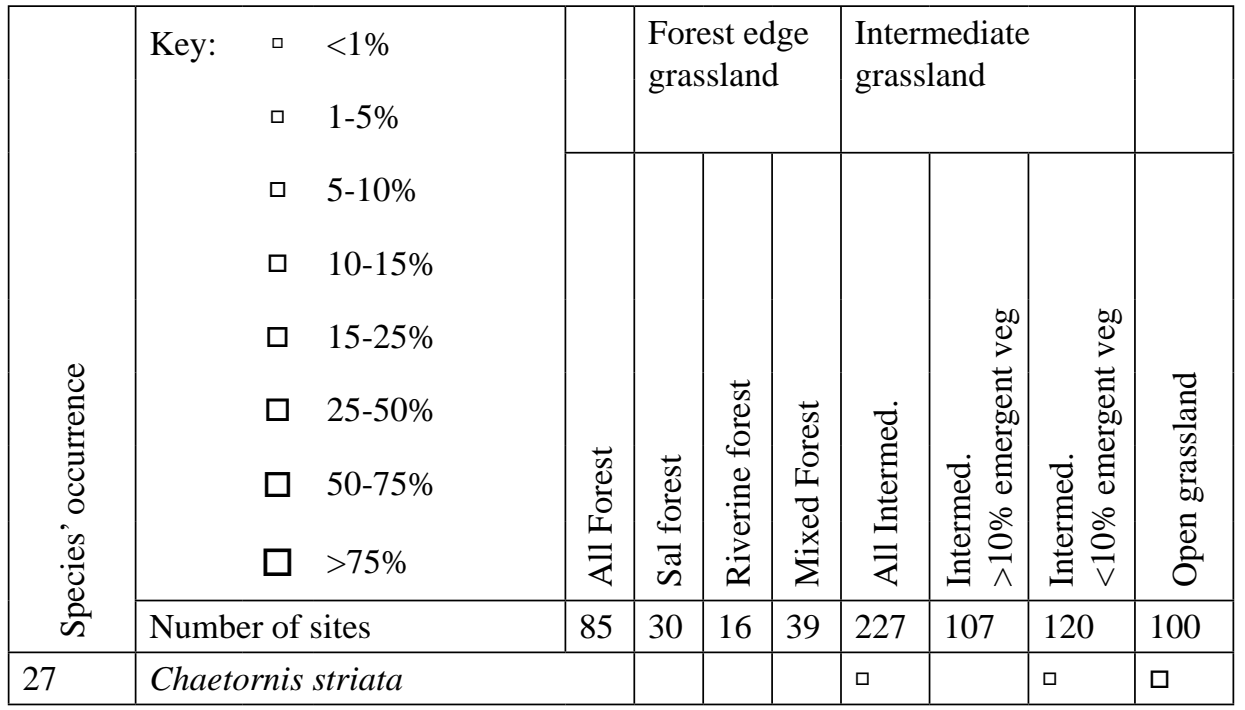

Figure 1:The percentage frequency of occurrence of Bristled Grassbird Chaetornis striata in grassland habitats classified by their distance from forest (DF) and proportion of emergent vegetation. Grasslands classified under three different categories: forest edge grasslands $(D F<100 \mathrm{~m})$, intermediate grasslands (DF 100-500m), open grasslands $(D F>500 \mathrm{~m})$.

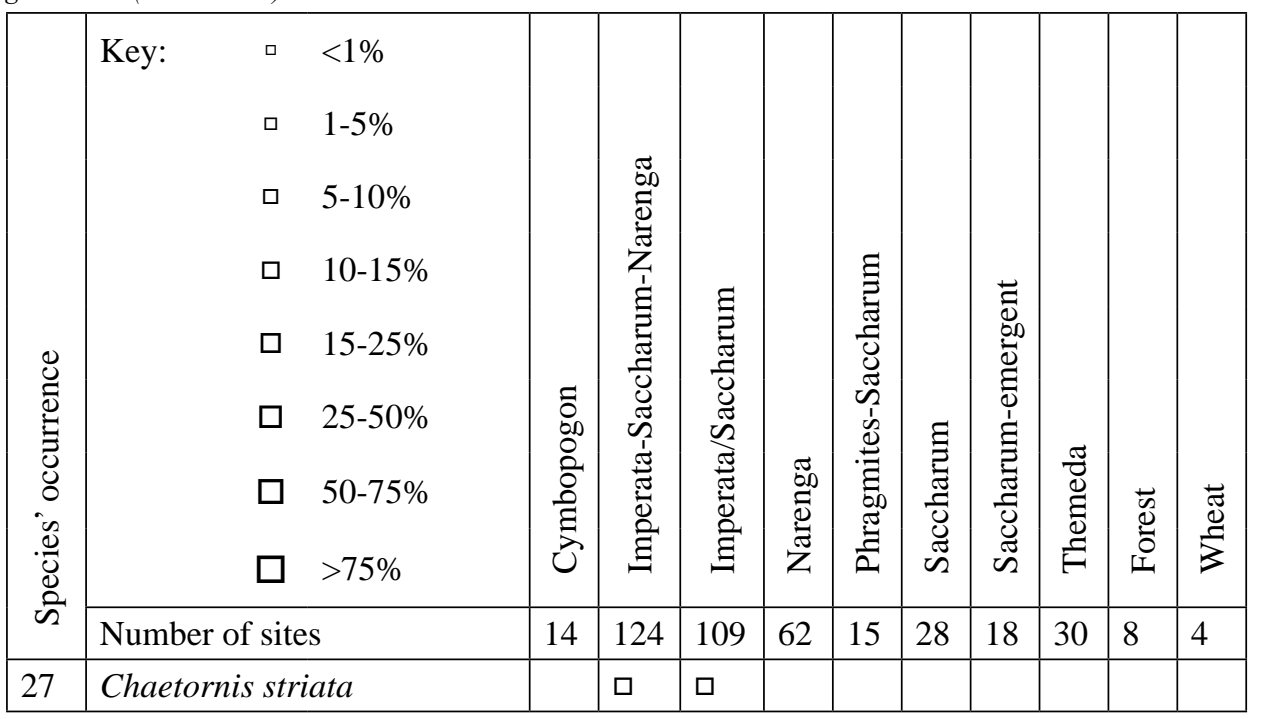

Figure 2: The percentage frequency of occurrence of Bristled Grassbird Chaetornis striata in grassland habitats classified by dominant grass species. 


\section{Status, Distribution and Population}

During summer survey, a total of 31 sites was searched for Bristled Grassbird of which 22 showed presence. A total of 115 birds was counted respectively at Chitwan (67), Sukla Phanta (31), Koshi (11) and Lumbini (6). The highest total for a single patch of continuous grassland was 25 from newly formed grasslands at Padampur Village in Chitwan.

The birds were recorded in the proper Sukla Phanta grassland but were absent from Singhpur, Rani Tal, Jhilmila, Sundari Phanta and Dudhia Phanta grasslands in Sukla Phanta. In properSukla Phanta, the main grass species were Imperata and Saccharum whereas in other phantas Narenga porphyrocoma, taller Saccharum bengalensis dominated. In Radhapur area, during the survey time, grasslands were heavily grazed and birds were absent. At Chitwan, birds were recorded from several grasslands along the Rapti River, the largest concentration being at Padampur grasslands. The main grass species were Imperata and Saccharum where these birds were recorded. In Koshi, they were found in newly formed grasslands (mostly Saccharum spontaneum) along the north south dyke on the east side of the river. Madhuban, Shukrabare, Kushaha and Titrigachhi grasslands were the main areas from where this bird was recorded. These localities changed every year because of annual flooding in Koshi River. Nevertheless as the bird utilized Saccharum/Imperata grasslands, this grass type was plentiful even outside the Protected Areas. In Lumbini, birds were recorded both inside and outside the Lumbini Master Plan Area in three different grassland sites which were dominated by shorter Imperata and Saccharum species.

\section{Status in winter}

At Chitwan, birds were not recorded on tape playback survey in 5 different grassland sites that held the highest number of Bristled Grassbird during summer survey. On 27 October 1997, one was noted perched on tall grass in Kachhuwani grasslands. This grassland was dominated by Narenga porphyrocoma with an average sward height of 6 metres, a different habitat than its normal summer habitat.

In Sukla Phanta, two birds were seen in the northeastern part of main Sukla Phanta grassland on 9 November 1997. Additionally, two were located in another grassland close to forest areas on 16 November 1997 making a total of four individuals for the area. However, when taped call was played in these places in December 1997 and March 1998 birds did not respond. During these months birds were also absent from wet grasslands of Phragmites karka and Saccharum arundinaceum in Rani Tal. Winter survey in March 1998 in various grassland sites of Bardia (Khauraha, Lamkauli and Baghaura Phanta) and Lumbini grasslands could not detect Bristled Grassbird.

\section{Morphometry}

Three birds were mist-netted with tape playback in Sukla Phanta. Measurements of wing, weight, bill and tarsus were taken (Table 1). Brood patch, fat, moult of the birds could not be detected. Two birds caught in May 1998 showed their tail feathers, all except central pair, tipped buff white. The tongue was yellow tipped with black and with dark colour mouth. Number of rictal bristles on either side usually five although, the smallest of the individuals caught had only four on its right hand side. 
Table1: Measurements of Bristled Grassbird taken in Sukla Phanta (f: bill length measured from the base of the feathering)

\begin{tabular}{|c|c|c|c|c|c|c|c|c|}
\hline \multirow[t]{2}{*}{ Date } & \multirow[t]{2}{*}{ Wing } & \multirow[t]{2}{*}{ Weight } & \multicolumn{3}{|c|}{ Bill } & \multirow[t]{2}{*}{ Tarsus } & \multirow[t]{2}{*}{\begin{tabular}{|c|}
$\begin{array}{c}\text { Tarsus } \\
\text { bent }\end{array}$ \\
\end{tabular}} & \multirow[t]{2}{*}{\begin{tabular}{|c|}
$\begin{array}{c}\text { Right hind } \\
\text { claw }\end{array}$ \\
\end{tabular}} \\
\hline & & & Length(f) & Width & Depth & & & \\
\hline 21-Мау-97 & 94 & 35 & 13 & 4.8 & 5.6 & 29.2 & 35 & $?$ \\
\hline 11-Мay-98 & 91 & 32.2 & 10.8 & 3.9 & 5 & 31.5 & 33 & 9.2 \\
\hline 11-Мау-98 & 93 & 33.2 & 13.1 & 4.6 & 5.1 & 31.1 & 34.8 & 9.6 \\
\hline
\end{tabular}

Of all the 115 individual birds (see also Appendix 1) observed during this survey (these were mostly located by listening to calls first), there were three individuals recorded from following places and dates (Table 2) that differed from the rest on a few morphological characters and behaviour. These individuals did not call like the males but two of them were heard producing short contact notes type of call. All three had paler upper mandible in contrast to horny grey or dark mandibles of all the other birds observed. These birds also had dark wash around the breast probably indicating age structure or sexual dimorphism.

Table 2: Date and locality of three unusual individuals of Bristled Grassbird

\begin{tabular}{|l|l|l|}
\hline \multicolumn{1}{|c|}{ Date } & \multicolumn{1}{|c|}{ Site/Area } & \multicolumn{1}{|c|}{ Observed peculiarity } \\
\hline 1 August 1997 & Padampur grasslands, Chitwan & $\begin{array}{l}\text { Pale upper mandible, dark } \\
\text { wash/streaks on the upper } \\
\text { breast }\end{array}$ \\
\hline 27 October 1997 & Kachhuwani grasslands, Chitwan & $\begin{array}{l}\text { Pale upper mandible, dark } \\
\text { wash/streaks on the upper } \\
\text { breast }\end{array}$ \\
\hline 9 November 1997 & $\begin{array}{l}\text { Sukla Phanta grasslands, Sukla } \\
\text { Phanta }\end{array}$ & $\begin{array}{l}\text { Pale upper mandible, dark } \\
\text { wash/streaks on the upper } \\
\text { breast }\end{array}$ \\
\hline
\end{tabular}

\section{Territory}

During the breeding season, birds were observed to be territorial and vigorously defending their territory. When approached towards a bird, it often called and started flying in the vicinity. A calling bird rose to a height usually 10 to 20 meters above the ground and flew around several minutes emitting its two-note call for at least 6 minutes. Call was "wheet-ss-s-stchew", the last note ending at rising tone. It was also observed that a calling male did not allow another active male within $100 \mathrm{~m}$ radius of the presumed territory. During peak summer months, several birds were heard calling in the air and flying nearly in an elliptical line. When taped call was played in its presumed territory, calling bird, possibly a male, came shooting towards the intruder. 
During May and June, most birds sang and secured territories. By the end of July, most of them had made nests and laid eggs. During this period, the frequency of the calls was already lower compared to May and June, although they continued calling till the end of August. No calls were generally heard by September and birds from this month onwards became more skulking and shy. Most of them virtually disappeared from these habitats by the end of October.

\section{Discussion}

Bristled Grassbird is widely distributed below $250 \mathrm{~m}$ all along the entire southern belt of Nepal where suitable habitat exists. All observations lead to the conclusion that this species is strongly associated with medium to tall, dense riverine grasslands in lowland terai. In summer, it is mostly recorded in Saccharum spontaneum and Imperata cylindrica grasslands. Imperata grasslands with interspersed Narenga patches is also inhabited by this species. The line of Sacchaurm patches along the major rivers outside the Protected Areas also contain small population of this species. It is found in dry as well as moist grasslands but is absent from wet Phragmites/Typha grasslands. Bristled Grassbird, Rufous-rumped Grassbird and Striated Grassbird are noted to occur together on moister areas of Shikari Tal marshes, Sukla Phanta. It avoids forested grasslands and prefers more open grasslands.

Presence of this species in more sites in Sukla Phanta reflects a higher number of Imperata dominated grasslands sampled there compared to other study areas. The grasslands in Chitwan and Koshi Tappu are equally important for the conservation of Bristled Grassbird. As many as 115 birds have been counted during summer and winter survey (Appendix 1).

The newly formed grassland across Rapti River, in Chitwan (formerly known as Padampur Village) is a promising habitat for Bristled Grassbird and several other threatened grassland species. Within an area of $1.5 \mathrm{~km}^{2}$ as many as 25 individuals have been observed, making this area with the highest concentration of Bristled Grassbird in Nepal and probably in its entire distribution range in the world. A total of $30 \mathrm{~km}^{2}$ area has been now covered with Saccharum spontaneum and other grass species in the former Padampur Village area. Nearly all the new vegetation has become a suitable habitat for Bristled Grassbird. In addition, Bengal Florican Houbaropsis bengalensis and Hodgson's Bushchat Saxicola insignis have been already recorded from here (Bishnu Mahato pers comm. 2001, Basu Bidari pers comm. 2001). In future these grasslands could also be colonised by the globally threatened Greycrowned Prinia Prinia cinereocapilla and Slender-billed Babbler Turdoides longirostris, both species occur in the adjoining grasslands.

Koshi Tappu is another important place for this species. All river islands that are colonised with Sachharum dominated grasslands are potential habitat. In recent years, because of better control of livestock grazing and illegal cutting of grasses in the Reserve, Koshi Tappu has seen healthy population of Bristled Grassbird.

Similarly, in Sukla Phanta degraded open grasslands have been restored soon after the Reserve extension. These include grasslands on the eastern side of the reserve e.g. 
Radhapur, Jhilmila, Beldandi and provide an additional habitat for a significant population of grasslandspecies. These instances also indicate that Bristled Grassbird may be a conservation dependent species.

Based on summer survey count of Bristled Grassbird and results regarding the status, distribution pattern and average population for the potential grassland habitat, an average density of 5 pairs $/ \mathrm{km}^{2}$ is proposed. If the total potential habitat for Bristled Grassbird in Nepal is $325 \mathrm{~km}^{2}$ then a figure of 1625 pairs or 3250 individuals is reached (Table 3 ). Exceptionally good habitat may show higher density and population but this density would not be applicable to all potential grassland habitats of Bristled Grassbird all over Nepal. Therefore, a conservative figure of 3250 individuals is presented.

Table 3: Total Protected Areas, grassland coverage, potential habitat outside and population estimate with four presumed density options

\begin{tabular}{|c|c|c|c|c|c|c|c|}
\hline Sites & $\begin{array}{c}\text { Total } \\
\text { Area/ } \\
\text { km }^{2} \\
\end{array}$ & $\begin{array}{c}\text { Total } \\
\text { Grassland/ } \\
\mathbf{k m}^{2}\end{array}$ & $\begin{array}{c}\text { Potential } \\
\text { Habitat/ } \\
\text { km}^{2} \\
\end{array}$ & $\begin{array}{c}\text { 25pairs/ } \\
\text { km² }^{2}\end{array}$ & $\begin{array}{c}\text { 10pairs/ } \\
\text { km² }^{2}\end{array}$ & $\begin{array}{c}5 \\
\text { pairs/ } \\
\mathbf{k m}^{2} \\
\end{array}$ & $\begin{array}{c}\text { 1pair/ } \\
\mathbf{k m}^{2}\end{array}$ \\
\hline $\mathrm{KT}$ & 175 & 122.5 & 50 & 1250 & 500 & 250 & 50 \\
\hline CNP & 932 & 186.4 & 100 & 2500 & 1000 & 500 & 100 \\
\hline BNP & 968 & 145.2 & 50 & 1250 & 500 & 250 & 50 \\
\hline SP & 305 & 62 & 50 & 1250 & 500 & 250 & 50 \\
\hline Others & & 100 & 75 & 1875 & 750 & 375 & 75 \\
\hline Total & 2380 & 616.1 & 325 & 8125 & 3250 & 1625 & 325 \\
\hline
\end{tabular}

The species is described as resident subject to local movements (Ali and Ripley, 1987), but capable of large distance migration (BirdLife International, 2001). Tape playback experiments as well as ringing in winter time in all these places have shown that Bristled Grassbird is primarily a summer visitor to Nepal. Rasmussen and Anderton (2005) have already pointed out that this bird is a summer visitor to Nepal and suggest parts of south India as its wintering area.

Based on this survey and our experience in the field, we have estimated the total bird population in Nepal using 4 density options and a potential habitat of $325 \mathrm{~km}^{2}$ for the bird in Nepal (Table 3). We have taken the option that all these potential grasslands will have an average of at least 5 pairs of birds per $\mathrm{km}^{2}$ with a total of 1625 pairs or a total of 3250 birds. If a population range is to be taken than 5 to 10 pairs $/ \mathrm{km}^{2}$ should be used although the latter density estimate may give highly exaggerated population figure. Pairs rather than individuals are used because most calling birds are males; and females that remain silent are harder to detect and count. In suitable grasslands e.g. Padampur grasslands as many as 15 nesting pairs have been estimated for the summer of 1997.

Mist-netting has been useful to find out the body condition, detailed study of plumages, and for morphometrics. However the mist-netting as an additional tool to record 'unseen' birds is not useful. This is mainly because the species during the breeding season spends 
considerable time perched on the top of the grasses and carrying out different breeding rituals (defending, feeding, etc.).

A nest was located in clumps of Saccharum spontaneum grass in the first week of August 1990 at Chitwan and details were noted (Baral, 1997). The grass clump was found amongst an open patch of shorter Imperata cylindrica grassland. The nest was placed horizontally in a short clump of grasses with only one horizontal opening (contra Ali and Ripley, 1987 who state vertical opening). It consisted mainly of grass materials (leaves, fine reeds and flowers). In 2004 adults have been seen carrying food at Koshi and a nest with young have been noted at Chitwan indicating their continued breeding in these two places (Badri Choudhary verbally, 2004). Birds have been seen vigorously defending their territory in Nawalparasi district, Lumbini, Bardia and Sukla Phanta during summer months indicating breeding of this species in all these localities.

Bristled Grassbird has been listed as Vulnerable based on historical decline of the species and threat to its habitat for a number of years (Collar et al., 1994; BirdLife International, 2012). The grasslands habitat of northern India and southern Nepal has been identified as one of the most threatened habitats in Asia and priority habitat for conservation (BirdLife International 2001).

Bristled Grassbird may conceivably still be a widespread resident and perhaps even locally common in suitable habitat (BirdLife International, 2001). In Nepal, it has been overlooked in the past for several reasons (Baral, 1997). First of all, ornithological contribution before 1990 was mainly from visiting foreign birders who chiefly visited between October and May. Secondly, bird watching activities during summer are restricted by the tall grasses that gain considerable height soon after receiving pre-monsoon showers in April and May. Finally, misidentification of the bird as Striated Grassbird has also led to a paucity of accurate data. This is why an overwhelming large number of records are post 1990 and especially after 1996 (BirdLife International, 2001). Now it is well established that with experience it is easily separable from other birds occurring in the same habitat (Heath and Thorns, 1989; Grewal, 1996; Baral, 1997).

\section{Threats}

The biggest threat to Bristled Grassbird is widespread habitat loss and deterioration in its entire range. Habitat has been lost mainly due to conversion of semi-natural grassland areas to agricultural fields. Major cause for the deterioration of grassland habitat is the overgrazing from the domesticated livestock. Most of Nepal's Protected Areas suffer from cattle grazing. The habitat of Bristled Grassbird along the edges of the Protected Area is under increased pressure due to cattle grazing and illegal grass cutting. Large rivers like Karnali and Narayani as well as Rapti act as the boundary of the park. Because of its proximity to human settlements the floodplains of the park boundary where naturally good growth of the grasses occur, is subjected to much human pressure. This pressure on the riverine grasslands at the edge of Protected Areas is threatening Bristled Grassbird population. The invasive alien species Mikania micrantha is posing serious problems to its habitat especially in Chitwan National Park. 


\section{Conservation recommendations}

A systematic and periodic survey of the birds in all the grasslands of the Protected Areas also covering newly formed grasslands in Sukla Phanta, e.g. those at Mahakali River, Karnali River, Bardia grasslands, newly described Khadara Phanta (Cox, 2002) and other grasslands in farmlands of Lumbini, in Chitwan along river courses, grasslands at Koshi Tappu (east and west as well those in the middle) and Koshi Barrage are important to establish a truer population status of the bird in Nepal. Bird population may differ annually affected by pre-monsoon conditions or other regimes. What kind of population fluctuation occurs and at what intervals of years will be an interesting find. A three-year interval nationwide monitoring scheme led by an experienced surveyor should be firmly established.

Historical winter records of Bristled Grassbird are mainly from south of Nepal viz India (Ali and Ripley, 1987; BirdLife International, 2001 and Rasmussen and Anderton, 2005). The bird should also be looked for outside the Indian subcontinent, especially where Striated Grassbird occurs. Misidentification as Striated Grassbird is more likely in wintering areas when territorial calls are not often heard. Even the most vocal birds are known to remain silent in winter, and it is possible that Bristled Grassbird remains mostly silent in winter. Winter habitat selection, range and migratory behaviour therefore require additional studies. It is also likely that the bird may use completely different habitat in winter which should be explored by further investigations.

Grasslands in the fringes of the Protected Areas and the newly formed grasslands along the rivers should be protected from cutting and cattle grazing. This type of intervention is necessary for all the threatened avifauna of lowland grasslands. In all the protected areas in lowland Saccharum-Imperata patches should be maintained.

These birds have been recorded also in unprotected site along the Bagmati River in the lowlands (Jack Cox Jr. verbally, 2003). Also several small patches of private grasslands at Koshi Tappu and Chitwan have held smaller population at various times. Local people should be made aware of the bird's significance and encouraged to protect Saccharum Imperata patches in their private lands. They should be encouraged to protect riverside grassland patches especially from cattle grazing from March to October.

To the advantage of the conservation community, its main breeding period coincides with a time when, although the needs for fodder and grasses remain the same, but are readily available in many places. This could help to take the pressure off from the main grassland sites where the birds actually breed.

A project led by Himalayan Nature and funded by the Critical Ecosystem Partnership Fund and WWF Nepal has recommended the Government of Nepal to list this species as protected under the National Parks and Wildlife Conservation Act 2029. 


\section{Acknowledgements}

Financial support to this study was provided by the Biodiversity Support Program, a consortium of World Wildlife Fund, The Nature Conservancy and World Resources Institute, with funding by the United States Agency for International Development. The study team likes to thank the management and staff of Chitwan Jungle Lodge, Gaida Wildilfe Camp and Silent Safari Pvt. Ltd. Thanks are also to Dr. Uday Raj Sharma, late Dr. Tirtha Man Maskey, former Director Generals of Department of National Parks and Wildlife Conservation, Uba Raj Regmi, Warden at Chitwan National Park and members of Grassland Bird Study Programme without whose help these areas could not have been covered; Sharad Singh, Sonam Bhutia, Tika Giri, Bishnu Mahato, Hathan Choudhary, Chamar Sing Gurung, Dukhi Ram Choudhary, Ram Parajuli, Sukhi Ram Choudhary, Harka Kumal, Shankar Tiwary, Basu Bindari, Badri Choudhary and Kanoon Choudhary.

We would like to thank Dr. Seb Buckton, Carol and Tim Inskipp and Professor Karan Bahadur Shah, Chairman of Himalayan Nature for comments on this paper all of which have significantly improved the presentation content.

\section{References}

Ali, S. and Ripley, S. D. 1987. Compact handbook of the birds of India and Pakistan. Second edition. Oxford University Press, Bombay.

Baral, H. S. 1990. Striated Marsh Warbler Megalurus palustris breeding in Chitwan. Unpublished.

Baral, H. S. 1996. Grassland Birds of Nepal. Bird Conservation Nepal Newsletter 4(4)/5(1):4.

Baral, H. S. 1997. Bristled Grassbirds Chaetornis striatus in Nepal. Danphe 6(2):5-6.

Baral, H. S. 2001. Community structure and habitat associations of lowland grassland birds in Nepal. University of Amsterdam, Amsterdam, The Netherlands.

Baral, H. S. and Inskipp, C. 2005. Important Bird Areas in Nepal: priority sites for conservation. Bird Conservation Nepal and BirdLife International, Kathmandu and Cambridge.

BirdLife International 2000. Threatened birds of the world. Lynx Edicions and BirdLife International, Barcelona and Cambridge.

BirdLife International 2001. Threatened birds of Asia: BirdLife International Red Data Book. BirdLife International, Cambridge.

BirdLife International 2012. IUCN Red List for birds. Downloaded from http://www. birdlife.org on 25/08/2012.

Collar, N. J., Crosby, M. J. and Stattersfield, A. J. 1994. Birds to watch 2: the world list of threatened birds. BirdLife International. Cambridge. 
Cox, J. 2002. Return to Kapilvastu. Danphe 11(2): 4-7.

Del Hoyo, J., Elliot, A. and Christie, D. A. (Eds) 2006. Hanbook of the birds of the world. Vol XI. Old World Flycatchers to Old World Warblers. Lynx Edicions, Barcelona.

Grewal, B. 1996. Bristled Grassbird Chaetornis striatus at Okhla, Delhi. Oriental Bird Club Bulletin 24: 43-44.

Grimmett, R., Inskipp, C. and Inskipp, T. 1998. Birds of the Indian Subcontinent. Christopher Helm. London, UK.

Gurung, K. K. 1983. Heart of the jungle. Andre Deutch, London.

Heath, P. J. and Thorns, D. M. 1989. Bristled Grass Warbler Chaetornis striatus new to and breeding in Nepal, and its separation from Large Grass WarblerGraminicolabengalensis. Forktail 4: 118-121.

Heinen, J. T. 1993. Park-people relations in Kosi Tappu Wildlife Reserve: a socio-economic analysis. Environmental Conservation 20(1): 25-34.

Inskipp, C. And Inskipp, T. P. 1991. A guide to the birds of Nepal. Christopher Helm, London.

Inskipp, T. 1996. Little known Oriental bird: Bristled Grassbird Chaetornis striatus. Oriental Bird Club Bulletin 24: 46-47.

IUCN 1993. Nature reserves of the Himalaya and the mountains of Central Asia. World Conservation Monitoring Centre. Oxford University Press, Gland, Switzerland and Cambridge, UK.

Laurie, W.A. 1979. The Ecology and Behaviour of the Greater One-horned Rhinoceros. PhD. Dissertation, University of Cambridge, Cambridge.

Peet, N. B., Watkinson, A. J., Bell, D. J. and Kattel, B. J. 1999. Plant diversity in the threatened subtropical grasslands of Nepal. Biological Conservation 88: 193-206.

Rasmussen, P. C. and Anderton, J. C. 2005. Birds of South Asia. The Ripley Guide. Vols. 1 and 2. Smithsonian Institution, Washington D.C., USA and Lynx Edicions, Barcelona, Spain.

Roberts, T. J. 1992. The birds of Pakistan. Vol. 2. Oxford University Press, Karachi.

Sharma, M. 2007. Bristled Grassbird Chaetornis striatus in Corbett National Park, India. BirdingASIA 7: 90-91. 
Appendix 1: Summary of records of Bristled Grassbird in lowland Nepal till early 1999

\begin{tabular}{|c|c|c|c|c|}
\hline Date & Site & No & Grassland type & Remarks \\
\hline & Chitwan & & & \\
\hline 24-Apr-86 & Meghauli grasslands & 1 & $\begin{array}{l}\text { Riverine grasslands, mainly } S \text {. } \\
\text { spontaneum and } I \text {. cylindrica }\end{array}$ & $\begin{array}{l}\text { Fleming in } \\
\text { litt. To Carol } \\
\text { Inskipp }\end{array}$ \\
\hline 6-May-86 & Meghauli grasslands & 5 & $\begin{array}{l}\text { Riverine grasslands, mainly } S \text {. } \\
\text { spontaneum and I. cylindrica }\end{array}$ & $\begin{array}{l}\text { Heath and } \\
\text { Thorns } 1989\end{array}$ \\
\hline 20-Jul-90 & $\begin{array}{l}\text { In front of Gaida Wildlife } \\
\text { Camp, Sauraha }\end{array}$ & 2 & $\begin{array}{l}\text { Riverine grasslands, mainly } S \text {. } \\
\text { spontaneum and I. cylindrica }\end{array}$ & \\
\hline \multirow[t]{2}{*}{ 3-Aug-90 } & $\begin{array}{l}\text { In front of Gaida Wildlife } \\
\text { Camp, Sauraha }\end{array}$ & $5+2 *$ & $\begin{array}{l}\text { Riverine grasslands, mainly } S \text {. } \\
\text { spontaneum and I. cylindrica }\end{array}$ & \\
\hline & Sukla Phanta & & & \\
\hline $\begin{array}{l}10-15 \\
\text { May } 1996\end{array}$ & Sukla Phanta Grasslands & 10 & $\begin{array}{l}\text { Mainly I. ylindrical with some } \\
\text { Saccharum spp. }\end{array}$ & \\
\hline $\begin{array}{l}\text { 19-May- } \\
97\end{array}$ & Sukla Phanta Grasslands & 4 & $\begin{array}{l}\text { Mainly I. ylindrical with some } \\
\text { Saccharum spp. }\end{array}$ & \\
\hline $\begin{array}{l}\text { 20-May- } \\
97\end{array}$ & Sukla Phanta Grasslands & 7 & $\begin{array}{l}\text { Mainly I. ylindrical with some } \\
\text { Saccharum spp. }\end{array}$ & \\
\hline \multirow[t]{2}{*}{$\begin{array}{l}\text { 22-May- } \\
97\end{array}$} & Sukla Phanta Grasslands & 7 & $\begin{array}{l}\text { Mainly Saccharum spp., } \\
\text { moist grasslands }\end{array}$ & \\
\hline & Chitwan & & & \\
\hline 5-Jul-97 & $\begin{array}{l}\text { In front of Gaida Wildlife } \\
\text { Camp, Sauraha }\end{array}$ & 13 & $\begin{array}{l}\text { Riverine grasslands, mainly } S \text {. } \\
\text { spontaneum and } I \text {. cylindrica }\end{array}$ & \\
\hline 1-Aug-97 & Gaida Wildlife Camp & 3 & $\begin{array}{l}\text { Riverine grasslands, mainly } S \text {. } \\
\text { spontaneum and I. cylindrica }\end{array}$ & \\
\hline Jun-97 & $\begin{array}{l}\text { Simara grasslands, Padam- } \\
\text { pur }\end{array}$ & 10 & $\begin{array}{l}\text { Riverine grasslands, S. spon- } \\
\text { taneum and I. cylindrical }\end{array}$ & \\
\hline 1-Aug-97 & $\begin{array}{l}\text { Simara grasslands, Padam- } \\
\text { pur }\end{array}$ & 25 & $\begin{array}{l}\text { Riverine grasslands, } S \text {. spon- } \\
\text { taneum and I. cylindrical }\end{array}$ & \\
\hline 31-Jul-97 & $\begin{array}{l}\text { Rapti River Grasslands, op- } \\
\text { posite of Sauraha }\end{array}$ & 2 & $\begin{array}{l}\text { Mainly } S \text {. spontaneum and } I \text {. } \\
\text { ylindrical. }\end{array}$ & \\
\hline 15-Jun-98 & Icharni grasslands & 5 & $\begin{array}{l}\text { S. spontaneum and I. ylindri- } \\
\text { cal with sparse stands of old } \\
\text { trees }\end{array}$ & \\
\hline 7-Sep-98 & $\begin{array}{l}\text { Between Simara and Gaida } \\
\text { Wildlife Camp }\end{array}$ & 12 & S. spontaneum grasslands & \\
\hline $\begin{array}{l}\text { 24-May- } \\
98\end{array}$ & West of Sauraha & 1 & S. spontaneum grasslands & \\
\hline 20-Sep-98 & In front of Sauraha & 8 & S. spontaneum grasslands & \\
\hline
\end{tabular}




\begin{tabular}{|c|c|c|c|c|}
\hline 5-Jul-97 & $\begin{array}{l}\text { Grasslands in the agricultural } \\
\text { fields }\end{array}$ & 1 & $\begin{array}{l}\text { Surrounded by agricultural } \\
\text { fields, small patch of Saccha- } \\
\text { rum grasslands }\end{array}$ & \\
\hline 2-Aug-98 & $\begin{array}{l}\text { Grasslands in the agricultural } \\
\text { fields }\end{array}$ & 3 & $\begin{array}{l}\text { Surrounded by agricultural } \\
\text { fields, small patch of Saccha- } \\
\text { rum grasslands }\end{array}$ & \\
\hline 6-Jul-97 & $\begin{array}{l}\text { Chaparchilli Grasslands, east } \\
\text { Chitwan }\end{array}$ & 1 & $\begin{array}{l}\text { Some Saccharum and Impe- } \\
\text { rata present but mainly Na- } \\
\text { renga, Themeda and other } \\
\text { Saccharum species present }\end{array}$ & \\
\hline 7-Jul-97 & $\begin{array}{l}\text { Rapti River floodplain, Chit- } \\
\text { wan Jungle Lodge }\end{array}$ & 1 & Ill growth of S. spontaneum & \\
\hline 26-Jul-97 & Meghauli grasslands & 5 & $\begin{array}{l}\text { Riverine grasslands, } S \text {. spon- } \\
\text { taneum and I. cylindrical }\end{array}$ & \\
\hline \multirow[t]{2}{*}{ 13-Apr-99 } & Chapparchilli Grassland & 1 & $\begin{array}{l}\text { Burnt } S . \text { spontaneum, Na- } \\
\text { renga porphyrocoma and } I \text {. } \\
\text { cylindrica }\end{array}$ & \\
\hline & $\begin{array}{l}\text { Lumbini (outside protected } \\
\text { area) }\end{array}$ & & & \\
\hline 10-Jul-94 & Lumbini grasslands & 6 & $\begin{array}{l}\text { S. spontaneum and I. cylin- } \\
\text { drica }\end{array}$ & \\
\hline \multirow[t]{2}{*}{$\begin{array}{l}\text { 31-Aug- } \\
97\end{array}$} & Lumbini grasslands & 2 & $\begin{array}{l}\text { S. spontaneum and I. ylindri- } \\
\text { cal, some shrubs also present }\end{array}$ & \\
\hline & Koshi Tappu & & & \\
\hline 15-Apr-99 & $\begin{array}{l}\text { Shukrabare, west bank of } \\
\text { Koshi River, KTWR }\end{array}$ & 2 & Unburnt $S$. spontaneum & \\
\hline 15-Apr-99 & $\begin{array}{l}\text { Madhuban, west bank of Ko- } \\
\text { shi River, KTWR }\end{array}$ & 3 & Unburnt $S$. spontaneum & \\
\hline 15-Apr-99 & $\begin{array}{l}\text { Kushaha, west bank of Koshi } \\
\text { River, KTWR }\end{array}$ & 3 & $\begin{array}{l}\text { Unburnt S. spontaneum and } \\
\text { Tamarisks }\end{array}$ & \\
\hline \multirow[t]{2}{*}{ 15-Apr-99 } & $\begin{array}{l}\text { Titrigachhi, east bank of Ko- } \\
\text { shi River, KTWR }\end{array}$ & 3 & $\begin{array}{l}\text { Unburnt S. spontaneum and } \\
\text { Tamarisks }\end{array}$ & \\
\hline & $\begin{array}{l}\text { WINTER RECORDS (from } \\
\text { 1997) }\end{array}$ & & & \\
\hline 27-Oct-97 & $\begin{array}{l}\text { Kachhuwani grasslands, } \\
\text { Chitwan }\end{array}$ & 1 & $\begin{array}{l}\text { Narenga porphyrocoma and } \\
\text { Themeda arundinacea }\end{array}$ & Yes \\
\hline 9-Nov-97 & $\begin{array}{l}\text { Sukla Phanta grasslands, } \\
\text { northeast part, Sukla Phanta }\end{array}$ & 2 & $\begin{array}{l}\text { Narenga porphyrocoma and } I \text {. } \\
\text { cylindrical }\end{array}$ & Yes \\
\hline $\begin{array}{l}16-\text { Nov- } \\
97\end{array}$ & $\begin{array}{l}\text { Sukla Phanta grasslands, } \\
\text { tower and northeast part }\end{array}$ & 2 & $\begin{array}{l}\text { Narenga porphyrocoma and } I \text {. } \\
\text { cylindrical }\end{array}$ & Yes \\
\hline
\end{tabular}

* pair with young 